"A few sparks of inspiration"?: Analysing the outcomes of European Union cultural policy coordination

Kate Mattocks

Centre for Culture and Creative Industries

City, University of London

Kate.mattocks.1@city.ac.uk

Northampton Square, London EC1V 0HB

United Kingdom

Telephone: $+44(0) 7449543993$

7,789 words 


\title{
"A few sparks of inspiration"?: Analysing the outcomes of European Union cultural policy coordination
}

\begin{abstract}
This article examines the outcomes of cultural policy coordination in the European Union using a case study of one policy priority in the 2011-2014 Work Plan for Culture. The Open Method of Coordination brings Member States together to exchange and cooperate on key policy priorities. Drawing on interviews with key actors as well as participant observation material, the article demonstrates the limited influence of the culture OMC on domestic policy, showing that domestic usage tends to be on the scale of individuals and organisations rather than Member State-wide. The article finishes by contextualising the outcomes, highlighting the constraints and challenges of intergovernmental coordination in fields where the EU holds a supporting competence.
\end{abstract}

\section{Keywords}

Policy coordination, cultural policy, Open Method of Coordination, culture, sociological institutionalism

\section{Introduction}

This article discusses the outcomes of European Union (EU) cultural policy coordination. ${ }^{1}$ The Open Method of Coordination (OMC), which takes place in sectors that the EU has partial or no formal competence in, is a non-legislative policy coordination process in which Member States cooperate on common policy objectives. It first started in the field of cultural policy in 2008. This focus of this article is examining whether the OMC has had any influence, using a case study of one policy priority in the 2011-2014 Work Plan for Culture. The aim of the paper is firstly to determine whether the OMC has resulted in any furthering of dialogue or progress in these policy areas (and if so, how the ideas and norms created in the context of the OMC are being used by national actors), and secondly, to further contextualise the outcomes by exploring the learning constraints and challenges of intergovernmental coordination in policy fields where the EU holds a supporting competence.

\footnotetext{
${ }^{1}$ Cultural policy typically encompasses policies relating to the arts and culture (including cultural institutions), communications and media (including, for example, broadcasting and publishing), citizenship and identity, and spatial culture (urban policy, cultural planning, and cultural heritage) (Craik, Davis, and Sunderland, 2000).
} 
Culture was first introduced as an EU competence in the 1992 Treaty of Maastricht. The Union's role is supplementary and Member States retain full control over their own cultural policies (for an overview of what the EU does in this field, see Craufurd Smith, 2004; Mattocks, 2017; Psychogiopoulou, 2015a). Culture is indeed a sector that Member States have traditionally been 'particularly disinclined' (Littoz-Monnet, 2007, p.2) to transfer more powers in, and development in this field is taken with strict conformity to the principle of subsidiarity. ${ }^{2}$ Culture presents unique challenges in that it is a policy area imbued with symbolic and political tensions, and is often used rhetorically to promote a sense of shared European identity. Compared to other sectors of EU public policy, cultural policy is rarely studied from a political science approach (exceptions include Littoz-Monnet, 2007, 2012; Mattocks, 2017; Psychogiopoulou, 2015; Staiger, 2009, 2013), likely because it is seen as an inconsequential policy area with little effect. This is particularly true in the case of policy coordination measures in the field, as much existing research on EU cultural policy tends to focus on implicit aspects of cultural policy (Ahearne, 2009) such as cultural identity (see Sassatelli, 2002; Schlesinger, 1997; Shore, 2000, 2001, 2006). However, because culture is often used as a "catalyst" for European integration (Staiger, 2009) and because its governance is imbued with tensions of competence and subsidiarity, it makes a good test case to examine the dynamics of EU policy coordination.

The aims of the culture OMC are to foster exchange of best practice between Member States; to structure cooperation around common strategic objectives; and to generate policy recommendations to inform EU and national policy-making. The emphasis is thus on the exchange of best practice and mutual learning, not policy harmonisation. I focus on Priority

\footnotetext{
${ }^{2}$ Subsidiarity, outlined in article 5(3) of the Treaty of Maastricht (TEU), is a principle of EU law. It says that the EU will only become involved in a policy area if it is deemed the best 'level' of government to do so, i.e. that Member States acting on their own is insufficient.
} 
A of the 2011-2014 Work Plan for Culture, which featured three OMC groups working on the themes of cultural diversity, intercultural dialogue and accessible and inclusive culture. The article proceeds as follows. I first give a brief overview of the methodological and theoretical approaches taken to determine the OMC's influence. This is followed by an introduction to the Open Method of Coordination and its transposition into the cultural field. I then discuss the outcomes of policy coordination, looking at examples of substantive policy change, procedural shifts, and mutual learning. Finally, the discussion section concentrates on learning constraints and explains why the OMC's influence has been so limited in this field.

\section{Evaluating coordination: theoretical and methodological approaches}

Empirical assessment of the OMC is 'extremely challenging' (Zeitlin, 2009, p.214). To make sense of the complexity of this topic, I have adopted a sociological institutionalism (SI) theoretical perspective, which argues that institutions, defined as stable, regularly occurring norms, rules, and patterns of behaviour, are the most important part of political life. Institutions both constrain and enable actors, who behave according to a logic of appropriateness (March and Olsen, 1989). They also create opportunities for and constrain learning. Institutional approaches are suited to studying policy coordination given their focus on formal and informal institutions as well as on socially-embedded norms and beliefs within these institutions (Bulmer, 1993).

In this approach, actors are conceptualised as 'conscious and reflexive [...] embedded in a given (institutional and indeed social) context' (Ripoll Servent and Busby, 2013, p.6). Member State experts who attend the OMC meetings adopt strategies that they see as appropriate. These in turn become routines that are reproduced in organisations (March and Olsen, 1989). The extension of the logic of appropriateness to the logic of practices (Jenson 
and Mérand, 2010) thus takes into account the importance of socially-constructed professional roles influencing preferences (From, 2002), overcoming one of the critiques of this perspective that actors simply "blindly" following rules without thinking.

Methodologically, I have used a qualitative, case study approach and a variety of research methods - document analysis, semi-structured interviews, and participant observation. Between April and December 2014, 30 semi-structured interviews were carried out among three different groups: EU officials in the European Commission and Council of Ministers, Member State representatives who attended the OMC meetings as nationally-appointed experts, and invited external experts from civil society platforms who presented to the groups. ${ }^{3}$ The sample is therefore a theoretical one. Anonymised quotations from interviewees, with assigned pseudonyms, are included in the discussion below. Additionally, in March 2015, I observed a two-day meeting of one of Priority A's three groups. Finally, where possible and applicable, findings have been corroborated with an evaluation survey on the culture OMC carried out by the consultancy firm Ecorys on behalf of the Commission (Ecorys, 2013).

There are numerous methodological challenges involved in evaluating a complex and multiscalar process such as the OMC. Policy learning in general is difficult to identify, much less "measure." It can only be identified through careful process-tracing and by using as many sources as possible. It is also difficult to isolate the OMC's influence (see Zeitlin, 2009), which is why triangulating data is recommended. An additional challenge is how we think of "success" and effectiveness. Success is a contested concept, and often, especially in the case

\footnotetext{
${ }^{3}$ Interviewees at the EU were initially contacted via heads of unit and then progressively via the snowball method. In the case of Member State experts and invited experts, these individuals were contacted via email using a publically-available participant list published in each OMC report.
} 
of the OMC, discussed in normative terms. As Borrás and Radaelli (2010, p.54) so simply put it, '[t]he literature is polarised between those who think that using the OMC is a good thing and those who do not.' There is no agreement on the yardsticks to evaluate success concepts because it is never articulated what a successful OMC might look like. Does success mean the production of a useful best practice manual? (And what would this look like?) Is a group successful if the experts themselves are happy with the outcome of the group? Or should the focus rather be policy change? One can easily see the challenges of this prickly concept.

In order to identify and evaluate the outcomes of coordination, I have used Jonathan Zeitlin's (2011) analytical typology to evaluate the 'influences, mechanisms, and effects' of the OMC. This is a comprehensive approach that takes into account a diverse spectrum of outcomes ranging from changes in national policies, to changes in capacity-building, and more subtle changes such as increased usage of concepts or increased awareness of policies in other Member States. This model is particularly relevant in the case of the culture OMC - an OMC that does not name policy harmonisation in its aims - because it encompasses a broad range of outcomes that go beyond "visible" policy change.

\section{Background: the Open Method of Coordination and its development in the field of} culture

The introduction of so-called "new" modes of governance dates back to the Lisbon Summit of March 2000 and the development of the 2000-2010 Lisbon Strategy, which aimed to make the EU 'the most competitive and dynamic knowledge-based economy in the world' (European Council, 2000). ${ }^{4}$ Since some of Lisbon's goals lay outside of the EU's jurisdiction,

\footnotetext{
${ }^{4}$ Similar, although "harder," policy coordination procedures were used in the lead-up to the adoption of the Euro.
} 
being wholly or majorly in the Member State domain, new strategies of coordination between Member States were created. The Open Method of Coordination was one of them. The OMC was designed to share best practice and achieve greater convergence between Member States based on establishing guidelines, indicators, targets, monitoring, and peer review; in other words, without legislative or hard law procedures. It also includes the participation of nonstate actors, social partners, and non-governmental organisations in its operation. It is thus a process 'respecting legitimate national diversity... without seeking to homogenise inherited policy regimes and institutional arrangements' (Zeitlin, 2005, p.218). Participation in the OMC by the Member States is voluntary. ${ }^{5}$

Insight from Kenneth Armstrong's (2010) work on policy coordination helps to shed light on why Member States coordinate policy. After all, "the mere resort to "coordination" as a technique of governance does not itself resolve debates about the allocation and exercise of competence: coordination still demands justification' (Armstrong, 2010, p.41). There are a spectrum of rationales for EU-level coordination, ranging from a damage control model of minimising spillover effects in the case of, for example, common economic or monetary policy (where states have "something to lose" if things go wrong), to looser coordination such as capacity-building and learning facilitation (Begg, 2008). The logic of coordination can therefore be cooperative or convergent (Biagi, 1998).

The first mention of an Open Method of Coordination in culture is in the European Commission's 2007 Agenda for Culture, which outlined the EU's overarching priorities for the cultural field (CEC, 2007). The culture OMC is different from most others in that it does

\footnotetext{
${ }^{5}$ In the case of the culture OMC, the participation rate in the first two cycles (2008-2010 and 2011-2014) was relatively high, with 20-25 Member States regularly participating (Ecorys, 2013).
} 
not feature target-setting, peer review, benchmarking, or naming and shaming (the one other exception being youth policy). ${ }^{6}$ It is an example of cooperative coordination as its goals are learning and exchange.

The culture OMC groups' work is based around triennial Work Plans which are approved by Member States in the Council of Ministers. The Work Plans contain 'Priority Areas' with specific sub-topics within each priority area. The first culture OMC groups started in 2008 under the 2008-2010 Work Plan for Culture. This cycle featured four OMC groups. The 2011-2014 Work Plan was unveiled in December 2010 and included ten OMC groups under six priority areas. The current Work Plan (2015-2018) was released in December 2014 and contains eight working groups in four priority areas. Each working group typically contains one appointed expert per participating Member State. The groups meet approximately six times within a period of roughly 18 months. As can be seen in Table 1 below, each group's task is to produce a good/best practice policy report. ${ }^{7}$ The reports represent a useable, tangible record of what has been achieved during the course of the OMC discussions, and, as they are made public and experts are encouraged to disseminate within their Member State and personal networks, are in theory useable to a much wider audience than those who took part in the OMC.

The focus of this article is Priority A, Cultural diversity, intercultural dialogue and accessible and inclusive culture, of the 2011-2014 Work Plan, which had three working

\footnotetext{
${ }^{6}$ There is no straightforward answer as to why this is the case, although the Agenda for Culture states that '[i]t is essential ... for the special features of the cultural sector to be fully taken into account in the design of an $\mathrm{OMC}$ in this area. [...] [T]his implies adopting a flexible approach, entailing the setting of general objectives with a light regular reporting system' (CEC, 2007, p.12).

${ }^{7}$ This terminology is used interchangeably by the Commission and participating experts.
} 
groups (see Table 1). ${ }^{8}$ Thematically, the groups concern pluralism and diversity in society; they concern two of the four core areas of cultural policy - arts and culture (including cultural institutions) and citizenship and identity (Craik, Davis, and Sunderland, 2000). Priority A is directly linked to the 2007 Agenda for Culture's first strategic objective, promotion of cultural diversity and intercultural dialogue, as well as the 'inclusive growth' priority (priority three) of Europe 2020.

\section{Insert Table 1}

Priority A is closely connected to ideas of European cultural identity and diversity, which has come to be a symbolic, politically-charged, and strategic narrative for the European Union (see Sassatelli, 2002; Shore, 2006). ${ }^{9}$ It also has close linkages with typical justifications for government involvement in the arts and culture at the national level, based on the idea of promoting and fostering "good" citizenship (Craik, Davis, and Sunderland, 2000). However, in the case of the EU, there is an assumption 'that culture can be harnessed unproblematically as a tool to promote the project of European construction' (Shore, 2001, p.117). The purpose of investigating Priority A is therefore to gain more insight into the politics of European cultural identity and diversity; how these issues are conceptualised and discussed in a supranational context; and whether EU policy coordination has any impacts in the Member States.

\footnotetext{
${ }^{8}$ The other priority areas in the 2011-2014 Work Plan are Cultural and Creative Industries; Skills and mobility; Cultural heritage including mobility of collections; Culture in external relations; and Culture statistics.

${ }^{9}$ As one Member State expert I interviewed put it, 'they are very much about values...these types of themes have high symbolic value' (Oskar, interview, June 2014).
} 
Rather than focusing on whether the OMC was successful or not, the article focuses on identifying the outcomes of policy coordination and exploring the factors that contributed to these outcomes. While the evaluation of the OMC in other fields often focuses on policy change, this does not accurately reflect the weak capacity of the culture OMC to produce significant convergence or change, largely due to the absence of indicators and targets (Laffan and Shaw, 2005). More importantly, nowhere in official documentation relating to the culture OMC is policy change or convergence mentioned, though Commission officials mentioned in interviews that the expectation is that the Member States "go home" and act on recommendations that emerge from the working groups. However, the consensus among Commission and Member State representatives is that the culture OMC is still too much in its infancy to be at the stage where substantive change is a realistic expectation but that it is an ideal aim for the future. That being said, it is crucial to look at whether the OMC achieves anything, since '...it is not just the capacity of the $\mathrm{OMC}$ to develop genuine policy debate which is important, but equally, the capacity of the policy debate to lead to concrete outcomes (solutions to issues of conflict)' (de la Porte, 2010, pp.20-1).

\section{Findings: the products and outcomes of policy coordination}

What outcomes did Priority A's working groups results in? The findings are structured based on Zeitlin's (2011) analytical typology, and, as per his categorisations, are split into three sections - substantive policy change, procedural shifts in governance and policy making, and mutual learning.

\section{Substantive policy change}

Zeitlin identifies three types of substantive policy change: cognitive shifts (changes in national policy thinking); political shifts (changes in national policy agendas); and 
programmatic shifts (changes in specific national policies). In Priority A's working groups, there was one example of a political shift: Lithuania launched a new cultural diversity policy in 2015. The policy comprised a Strategy for Development of National Minorities and an Action Plan for Integration aimed at 'increasing public tolerance through intercultural dialogue' (Ministry of Culture of Lithuania, 2015). This was an extension of the previous national strategy (2012-2014) and focused on the integration of the Roma population into Lithuanian society. The policy encompasses a broad range of areas including education, health, labour market participation, and cultural measures. It is in the latter section where the OMC's influence can be seen.

As a part of the launch of the new policy, the country hosted a national conference on diversity and intercultural dialogue, to which several members of the OMC group on that subject contributed: the chair of the group, from Slovenia, delivered a presentation on the group's report, and two other members presented examples of 'policy in practice' initiatives from their Member States (Paulina, expert, interview, June 2016). Although it is impossible to isolate the OMC's impact among a large range of potential influences (including other EU influences such as the EU Framework for National Roma Integration Strategies up to 2020 [Council of the European Union, 2011]), experts indicated that participation in the OMC group played a part with regards to the section of the policy on intercultural dialogue (Paulina, expert, interview, June 2016; Viktoria, expert, interview, October 2014).

Priority A's consultations did not find any other evidence of substantive policy change, making it the exception rather than the rule. This finding is consistent with findings from the culture OMC more generally (Psychogiopoulou, 2015b) and reflects the critical lens of much research on the $\mathrm{OMC}$, that there is a 'highly limited role for the EU common objectives, 
acting as a general normative context generating little adaptation pressures' (Armstrong, 2010, p.186). This will be discussed in more detail in the following section.

\section{Procedural shifts}

Zeitlin's second major category of change is procedural shifts in governance and policymaking. He includes five types of shifts: strengthened horizontal integration of interdependent policy fields; improvements in national steering and statistical capacities; enhanced vertical coordination; increased involvement of non-state actors in policymaking; and the development of new networks for the involvement of non-state and subnational actors in EU policy coordination processes. This category is not as relevant for culture as it is with other OMCs, as changes in this category are often associated with increased horizontal and vertical capacity building due to reporting statistics and monitoring, which the culture OMC does not feature. However, there was one example of enhanced vertical coordination in a country that hosted a study visit. ${ }^{10}$ Activities organised during the study trip meant that people who worked for the national Ministry of Culture met employees from regional authorities and regional arts organisations. These people were brought together for the first time because of the OMC and began to cooperate on other initiatives because of it; there is now more formal and informal coordination on cultural matters between the national government and this region in the Member State (interview, Nils, expert, June 2014).

In addition, there was also another example of a new network: one participating expert was in the process of establishing a pan-European cultural network and she invited new members who she met through the OMC to participate in the project (Paulina, expert, interview, June

\footnotetext{
${ }^{10}$ Study visits, a meeting outside Brussels, usually take place once per group.
} 
2014). More generally, several experts reported that the best thing about taking part in the OMC was meeting new like-minded people and expanding their professional networks (various interviews, June-October 2014). Interestingly, this occurred mainly in an informal fashion, as many experts criticised the formal OMC process for what they saw as too little focus on getting to know one another. A social programme is not automatically built into the meetings (with the exception of the study visits), but those who made an effort to connect with colleagues socially experienced benefits, as evidenced by this comment from expert Timo:

... the chance to spend some free time with some colleagues - we had a few hours before the flight ... it was a good chance to talk. It was useful. [In the meetings themselves], it was impossible to achieve this level of interaction (interview, October 2014).

The extent to which these partnerships continued on past the OMC groups varied considerably, as one might expect. However, many experts find meeting new people the most satisfying part of the entire $\mathrm{OMC}$ process. In this respect the $\mathrm{OMC}$ represents a unique meeting place for like-minded individuals:

[T] hrough these working groups we've gotten to know each other quite well and gotten to know their work. So there's a behind the scenes dialogue taking place within these groups (Paulina, expert, interview, June 2014).

Paulina's use of "behind the scenes" reinforces the unintended nature of this outcome. This was also a finding in the Ecorys survey, which reported that '[c]ommunities of practice, interest and knowledge networks are also developing as a result of the OMC process' (p.28). The survey found that $51.4 \%$ of surveyed group reported that developing new networks was relevant 'to a great extent' and $42.9 \%$ 'to some extent' (p.39).

\section{Mutual learning}


A third category of influence is mutual learning, of which there are three types: heuristic learning, the increased awareness of policies and practices in other Member States; increased capacity-building; and maieutic/reflexive learning, the "gentlest" form of learning, which refers to increases in states' abilities to rethink and re-evaluate policies and programmes. Perhaps unsurprisingly given its goals and low capacities to incite change, it is in this category that we see the most influence of the culture OMC.

The culture OMC has led to heuristic learning, an increase in awareness of policies and programmes in other Member States and the EU. This means that even if policies or programmes do not change, there is an increased awareness of what prospective changes might look like, even if they 'remain subject to controversy and debate' (Zeitlin, 2009, p.229), as shown by these comments from two participating experts:

No. I can't see that policy has changed much, but actually - it's a big but - the OMC consultations, meaning all the various groups and their outcomes - have really contributed to raising awareness, both within the administration in [country] and also outside in the field (Luise, interview, June 2014)

What you learn in the working groups are not about big developments, but how you do it in little steps, and about learning what ideas are out there (Ruth, interview, July 2014).

Darya, a member of a national government, spoke more generally and said that, We had some examples of OMCs that saved us a lot of work. [...] [One in particular ${ }^{11}$ ] was for [the policy officer] a fast-forward trip, and very useful. So that was absolutely worth the investment and even paid back more than it cost. But that might be the exception. Mostly it's

\footnotetext{
${ }^{11}$ This OMC group Darya is referring to is not in Priority A.
} 
a lot of uninteresting "blah blah blah" and then maybe a few sparks of inspiration (Darya, personal communication, April 2014).

In terms of maieutic/reflexive learning, one of the main influences of the $\mathrm{OMC}$ is that recommendations coming from the EU can lend credibility to discourses that may not be well-established in a domestic context. This is known as the leverage effect, whereby EU discourse is used 'as a tool to advance [...] domestic political agendas, promote desired reforms, and overcome entrenched veto positions' (Zeitlin, 2005, p.480). It allows experts, as change agents, to promote ideas with more political weight behind them (Ecorys, 2013). Indeed, the most common type of influence of Priority A is the personal usage of the best practice reports and the ideas in them, which may translate into small-scale impacts. Many experts use and share the report and incorporate what they have learned into their own practices, showing a range of appropriation by domestic actors. Therefore, 'by embracing OMC concepts, categories, and metrics ... domestic actors at a minimum acknowledge and reinforce the discursive legitimacy of common European objectives and policy approaches' (Zeitlin, 2009, p.233). It may also lead to information-seeking from other sources such as other EU venues, platforms, or non-governmental organisations.

\section{Discussion: learning constraints}

This section expands on the findings above and explains why the culture OMC has produced these types of outcomes and not others. Little "observable" policy change has occurred in Priority A. Why is this the case? The discussion below highlights four fundamental learning constraints: a lack of overarching aims of the culture OMC; the loose and vague nature of themes; the weak connection between domestic and EU politics in this field; and the low visibility of the culture OMC. 
The first key reason for the limited and local nature of outcomes in Priority A is that there is a lack of overarching narrative about why Member States coordinate cultural policy to begin with, and alongside this, what the role of culture and cultural cooperation is in the European Union. Culture is emphasised as a vehicle to forge popular support for European integration and to foster a sense of common European identity (Shore 2000, 2006). However, despite the assertion that 'culture is an indispensable feature to achieve the EU's strategic objectives of prosperity, solidarity and security' (CEC, 2007, p.3), there is a lack of understanding of how this works in practice. There is also a paradox at play: cultural cooperation is desired in order to further European integration and unity, but its development is constrained by subsidiarity and Member States' wishes to keep culture a national competence (Patel, 2013). Policy coordination therefore exists, but it is driven by the European Commission rather than the Member States (Mattocks, 2016).

A second reason to explain these outcomes is the loose and vague nature of the themes the groups work on. Referring back to Table 1, we see that the groups' tasks are very broad. Borrás and Radaelli (2010) argue that ambiguity and broad-brush goals to achieve maximum political agreement are in fact built into the OMC's institutional design. The OMC's common objectives therefore act as loose themes for discussion, rather than problems to be solved. There are also conceptual difficulties in establishing basic frames for discussion among 28 Member States, who lack a ‘typology of similarity' (March and Olsen, 2009) for a common framework, even language, of cultural policy, making firm outcomes even more challenging. One argument prominent in the OMC literature is that vagueness is embraced by the Member States in order to protect subsidiarity (Lodge, 2007): “[o]pponents of a powerful "social Europe"" have not been willing to allow any EU competence in this arena; they have, 
however 'been willing to allow the operation of the OMC in this field, as they see the OMC as a rather innocuous exercise that entails no binding commitments' (Idema and Kelemen, 2006, p.117). This is also what we see in the case of culture: there is little political will to formulate more concrete goals or introduce a firmer style of coordination (Littoz-Monnet, 2007; Mattocks, 2016).

A third reason to explain the limited nature of outcomes is that there is a weak connection between domestic and EU politics and policy in this field. To understand this we have to look at the role of the Member States in the culture OMC. The main output of the culture OMC is the best practice reports, which contain policy recommendations. The incorporation and use of these recommendations into domestic policy depends on the roles of two groups of actors: national ministries of culture and the appointed experts. Influence ultimately depends on two key factors. The first is whether the participating expert, acting as a change agent, is able to "get behind" the results. Does he or she find the results credible and appropriate? Here, the expert will be influenced by their own professional experience as well as expectations of appropriate behaviour emanating from the Member State (From, 2002; Ripoll Servent and Busby, 2013). No matter what job or connections the expert holds, if he or she does not take "ownership" of the recommendations, there is much less chance that they will be implemented.

Even if the expert does find the recommendations appropriate, this does not mean that the recommendations will be adopted. This is because national cultural ministries become gatekeepers (Dawson, 2009) and determine what, if anything, happens with the groups' findings post-OMC. Because the experts taking part in the meeting are usually not highlyranked officials with the capacity to make key decisions, they rely on instructions "from 
above" as to the nature of their OMC participation. Any post-OMC change thus relies on senior officials who must be convinced by the recommendations and find them appropriate (Schmidt and Radaelli 2004b), as is evident in these frustrations echoed by expert Wasil: I am having a struggle at [my place of employment], getting my superiors interested in these issues. [...] it's a matter of will (interview, October 2014).

Policy and election cycles are also important in this respect. For example, one expert, a policy advisor in a regional government, said that in the first of three OMCs she had participated in, there was more domestic interest one in particular as of the theme was 'very much in accordance with what we were doing at the time' (Hanna, interview, May 2014). Therefore, if the policy theme in question is in harmony with current policy priorities (or impending changes in them), and if political circumstances are optimal (for example, the election-cycle timing is optimal), there is also a higher chance that there will be domestic usage of the OMC's recommendations.

EU policy coordination is ultimately 'mediated by national needs, ambitions, and capacities which are, in turn, shaped by domestic political and administrative opportunity structures' (Kassim, Peters, and Wright, 2000, p.18; emphasis added). My findings revealed that some ministries are much more purposeful about their participation in the $\mathrm{OMC}$ and others are much more random, reflecting diversity in Member States' approaches to policy coordination in this field. Experts often attend with little idea what is expected of them, which means that it is less likely that participation will lead to outcomes unless the expert 'pushes' hard for them to be taken into consideration.

Finally, a fourth reason for limited outcomes is that the culture OMC is in fact a rather closed process with low visibility in the EU and domestically. One invited expert summed it up 
when she said that 'what happened inside the room was barely known to the other people in the building!' (Camilla, interview, November 2014). The weaknesses of dissemination is an issue that the Commission knows could be improved, as demonstrated from this quote by Commission official Jette:

...in terms of the output, certainly the dissemination at the national level has to be improved. Sometimes you've got the impression that the reports end up on the shelves and aren't used anymore (Jette, Commission, interview, May 2014).

So, while there is a small community of practice emerging, this community is not being replicated at the domestic level (or if it is, there is only a small number of actors involved); there is thus a 'de-coupling between the EU networks operating in the OMC processes and the domestic networks that decide on policy reforms' (Borrás and Radaelli 2010, p.46-7). The OMC's impact on domestic cultural policy is uneven and localised (sometimes only individual) rather than on a national scale.

\section{Conclusions}

The discussion herein has demonstrated the limited nature of influences in Priority A of the 2011-2014 Work Plan groups. The range of outcomes as well as the nature of policy lag means that labelling these findings as "successes" or "failures" is not terribly useful; rather, they should be understood in a more contextualised manner in terms of the logic and design of policy coordination.

A sociological institutionalism approach to policy learning, conceptualising learning is a socially constructed, emergent, and ongoing process, has allowed for a focus on when policy learning and change are most likely. Because there is no domestic adaptation pressure, expert and Member State take-up of the ideas and recommendations in the OMC report was found to 
be higher the more legitimate and appropriate the recommendations are perceived to be: ' $[\mathrm{t}]$ he story the discourse tells and the information it provides must also appear sound, the actions it recommends doable, the solutions to the problems it identifies workable, and the overall outcomes appropriate' (Schmidt and Radaelli, 2004a, p.201).

Despite the voluntary nature of the $\mathrm{OMC}$, there is some sense that concepts such as intercultural dialogue and access to culture are gaining heuristic exposure within Member States' cultural ministries, evidenced by many experts who said that there is more awareness of EU policy priorities and concepts as a result of the OMC. Through the OMC there is therefore an 'expansion of a unique vocabulary into increasingly common knowledge' (Christiansen, Jørgensen, and Wiener, 2001, p.15). Indeed, the themes of Priority A's groups have been prominent themes in EU cultural policy since 2007; cultural diversity and intercultural dialogue are the first of three priorities in the 2007 Agenda for Culture. However, the Ecorys survey found that

[t]he European added value of the Culture OMC lies primarily in providing opportunities for mutual learning on issues of common interest, which would not otherwise be available to participants (Ecorys, 2013, p.28; emphasis added).

This suggests that while the OMC may be successful at creating opportunities for exchange, this does not necessarily translate into concrete outcomes. Despite this study's focus on one policy priority, this is reflective of the culture OMC more widely (Psychogiopoulou, 2015b).

One of the stand-out findings is that many issues that face the culture OMC are in fact shared across the OMC more broadly. Results from studies in other fields have shown low levels of policy change and learning and demonstrated various concerns about the design of policy coordination and issues such as under-conceptualisation, de-politicisation, and an absence of 
clearly articulated aims (see Armstrong, 2010; de la Porte, 2010; Kerber and Eckardt, 2007; Kröger, 2008, 2009; Lodge, 2007). The OMC is a "soft" tool, designed as a flexible system that allows Member States to give and take as little or as much as they want from participation. It exists "not to constrict actors within a prescriptive framework" (Regent, 2003, p.198), but to allow each state to adapt as it sees fit. However, this has led to fundamental paradoxes in its logic between a participatory and deliberative modus operandi versus a convergent and compliant one (Borrás and Radaelli 2010, p.47). Moreover, and perhaps most importantly, '[t]he collective experience of successive cycles of policy coordination and the potential limits to the utility of co-ordination has not translated into a serious debate about extending EU competence' (Armstrong, 2008, p.420). There is little sense that policy coordination will transform into deeper cooperation on cultural matters.

The OMC is a unique way of cooperating between Member States, and its key strength is in its potential for the creation of a common language and framework for discussion, rather than in its capacity to produce substantial concrete outcomes. A more positive outlook might say that the OMC has the eventual potential to evolve into something more concrete and outputoriented, whereas a more negative one would say that the culture OMC is not likely to live up to its "ideal-type" due to fundamental issues with its conceptualisation and design. Despite its conceptual challenges, the culture OMC is still rather in its infancy:

Change, best practice, and so on - it starts in the OMC groups. [...] Of course [...] changes do not always happen from one moment to the next, it may be a year or two years later, but how much this collective work, experts, has fed into national and regional policies, to what extent, that is something to see in the future (Fatima, Commission policy officer, interview, May 2014). 
[Y]ou'd never manage to do it [policy change] at the same time, because all policy cycles are different. But I do believe that [we're] building a body of experience (Jette, Commission policy officer, interview, May 2014).

Ultimately, 'in the absence of a single European public space, there are myriads of European niches, each providing a distinct meeting place for participants from all member states with shared interests' (de Swaan, 2007, p.137). The OMC is one such niche. The article has shown that while a community of practice is emerging, this community is not being replicated at the domestic level (or if it is, there is only a small number of actors involved) - thus it truly is a niche. In its current form, therefore, the influence of Priority A is limited and most often occurs at an individual or organisational scale, not translating into broader influences within the Member States. 


\section{References}

Ahearne, J. (2009) Cultural policy explicit and implicit: a distinction and some uses, International Journal of Cultural Policy, 15(2), pp. 141-153.

Armstrong, K. (2008) JCMS symposium: EU governance after Lisbon, Journal of Common Market Studies, 46(2), pp. 413-426.

Armstrong, K. (2010) Governing Social Inclusion: Europeanization through Policy Coordination (Oxford: Oxford University Press).

Begg, I. (2008) Is there a convincing rationale for the Lisbon Strategy? Journal of Common Market Studies, 46(2), pp. 427-435.

Biagi, M. (1998) The Implementation of the Amsterdam Treaty with Regard to Employment: Co-ordination or Convergence? International Journal of Comparative Labour Law and Industrial Relations 14, pp. 325-336.

Borrás, S. and Radaelli, C. (2010, December) Recalibrating the open method of coordination. Swedish Institute of European Policy Studies, Stockholm, Sweden.

Bulmer, S.J. (1993) The Governance of the European Union: a New Institutionalist Approach, Journal of Public Policy, 13(4), pp. 351-380.

Christiansen, T., Jørgensen, K.E. and Wiener, A. (2001) Introduction, in T. Christiansen, K.E. Jørgensen \& A. Wiener (Eds) The Social Construction of Europe, pp.1-19 (London: Sage).

Commission of European Communities (CEC) (2007) Communication from the Commission to the European Parliament, the Council, the European Economic and Social Committee and the Committee of the Regions. Communication on a European agenda for culture in a globalizing world. COM(2007) 242 final, 10 May.

Council of the European Union (2010) Work Plan for Culture 2011-2014. Document 2010/C $325 / 01$.

Council of the European Union (2011) EU Framework for National Roma Integration Strategies up to 2020. Document 10658/11, 24 May.

Craik, J., Davis, G. and Sunderland, N. (2000) Cultural policy and national identity, in: G. Davis \& M. Keating (Eds) The Future of Governance: Policy choices, pp. 177-202 (St. Leonards, Australia: Allen \& Unwin).

Craufurd Smith, R. (Ed.) (2004) Culture and European Union Law (Oxford: Oxford University Press).

Dawson, M. (2009) EU law 'transformed'? Evaluating accountability and subsidiarity in the 'streamlined' OMC for Social Inclusion and Social Protection, in S. Kröger (Ed.) What we have learnt: Advances, pitfalls and remaining questions in OMC research, European 
Integration online Papers (EIoP) 13(1). Available at: http://eiop.or.at/eiop/texte/2009008a.htm (accessed 11 July 2016).

De la Porte, C. (2010) State of the Art: Overview of concepts, indicators and methodologies used for analyzing the social OMCs. Working paper no. 54, Reconciling Work and Welfare in Europe (RECWOWE), Belgium.

De Swaan, A. (2007) The European void: the democratic deficit as a cultural deficiency, in J.E. Fossum \& P. Schlesinger (Eds) The European Union and the Public Sphere: A communicative space in the making? (London and New York: Routledge).

Ecorys (2013) Evaluation of the open method of coordination and the structured dialogue, as the Agenda for culture's implementing tools at European Union level: final report for the European Commission Directorate-General for Culture and Education.

European Council (2000) Presidency Conclusions. Lisbon European Council of 23 and 24 March 2000.

From, J. (2002) Decision-making in a complex environment: a sociological institutional analysis of competition policy decision-making in the European Commission, Journal of European Public Policy, 9(2), pp. 219-237.

Idema, T. and Kelemen, R.D. (2006) New methods of governance, the open method of coordination and other fashionable red herring, Perspectives on European Politics and Society, 7(1), pp. 108-123.

Jenson, J. and Mérand, F. (2010) Sociology, Institutionalism and the European Union, Comparative European Politics, 8(1), pp. 74-92.

Kerber, W. and Eckardt, M. (2007) Policy learning in Europe: the open method of coordination and laboratory federalism, Journal of European Public Policy, 14(2), pp. 227-247.

Kröger, S. (2008) Soft governance in hard politics. European coordination of anti-poverty policies in France and Germany (Wiesbaden: VS Verlag).

Kroger, S. (2009) The Open Method of Coordination: Underconceptualisation, overdetermination, de-politicisation and beyond, in S. Kröger S (Ed.) What we have learnt: Advances, pitfalls and remaining questions in $\mathrm{OMC}$ research. European Integration online Papers, 13(1). Available at: http://eiop.or.at/eiop/pdf/2009-005.pdf (accessed 11 July 2016).

Laffan, B. and Shaw, C. (2005) Classifying and mapping OMC in different policy areas. NEWGOV: New modes of governance. Available at: http://www.eunewgov.org/database/DELIV/D02D09 Classifying and Mapping_OMC.pdf (accessed 11 July 2016).

Littoz-Monnet, A. (2007) The European Union and Culture: between Economic Regulation and Cultural Policy (Manchester: Manchester University Press).

Littoz-Monnet, A. (2012) Agenda-setting Dynamics at EU Level: the case of the EU's Cultural Policy, Journal of European Integration, 34(7), pp. 505-522. 
Lodge, M. (2007) Comparing Non-Hierarchical Governance in Action: The Open Method of Co-Ordination in Pensions and Information Society, Journal of Common Market Studies, 45(2), pp. 343-365.

March, J.G. and Olsen, J.P. (1989) Rediscovering institutions: the organizational basis of politics (New York: The Free Press).

March, J.G. and Olsen, J.P. (2009) The Logic of Appropriateness. ARENA Working Paper, Centre for European Studies, University of Oslo, Norway.

Mattocks, K. (2016) Intergovernmental coordination in European Union cultural policy: the Open Method of Coordination and the 2011-2014 Work Plan for Culture. PhD thesis, City University London.

Mattocks, K. (2017) Uniting the Peoples of Europe? Exploring the European Union's Cultural Policy Agenda, forthcoming in: D. O'Brien, T. Miller \& V. Durrer (Eds) Routledge Companion to Global Cultural Policy (London: Routledge).

Ministry of Culture of Lithuania (2015) Action Plan for Roma Integration into the Lithuanian Society for 2015-2020. Order No. IV-48, 29 January.

Patel, K.K. (2013) The Cultural Politics of Europe: European Capitals of Culture and European Union since the 1980s (London: Routledge).

Psychogiopoulou, E. (Ed.) (2015a) Cultural governance and the European Union: protecting and promoting cultural diversity in Europe (Basingstoke: Palgrave Macmillan).

Psychogiopoulou, E. (2015b) The Cultural Open Method of Coordination, in: E. Psychogiopoulou (Ed) Cultural governance and the European Union: protecting and promoting cultural diversity in Europe, pp. 37-46 (Basingstoke: Palgrave Macmillan).

Regent, S. (2003) The open method of coordination: a new supranational form of governance? European Law Journal, 9(2), pp. 190-214.

Ripoll Servent, A. and Busby, A. (2013) Introduction: Agency and influence inside the EU institutions, in: A. Ripoll Servent \& A. Busby (Eds) Agency and influence inside the EU institutions. European Integration online Papers (EIoP), Special Issue 1(17). Available at: http://eiop.or.at/eiop/texte/2013-003a.htm (accessed 11 July 2016).

Sassatelli, M. (2002) Imagined Europe: The shaping of a European cultural identity through EU cultural policy, European Journal of Social Theory, 5(4), pp. 435-451.

Schlesinger, P. (1997) From cultural defence to political culture: media, politics and collective identity in the European Union, Media, Culture \& Society, 19(3), pp. 369-391.

Schmidt, V.A. and Radaelli, C.M. (2004a) Policy change and discourse in Europe: conceptual and methodological issues, West European Politics, 27(2), pp. 183-210. 
Schmidt, V.A. and Radaelli, C.M. (2004b) Conclusions, West European Politics, 27(2), pp. 364-379.

Shore, C. (2000) Building Europe: The Cultural Politics of European Integration (London and New York: Routledge).

Shore, C. (2001) The cultural policies of the European Union and cultural diversity, in: T. Bennett (Ed.) Differing diversities: cultural policy and cultural diversity pp. 107-121 (Strasbourg: Council of Europe Publishing).

Shore, C. (2006) "In uno plures"(?) EU Cultural Policy and the Governance of Europe, Cultural Analysis, 5, pp. 7-26.

Staiger, U. (2009) New agendas? Culture and citizenship in EU policy, International Journal of Cultural Policy, 15(1), pp. 1-16.

Staiger, U. (2013) The European Capitals of Culture in context: cultural policy and the European integration process, in: K.K. Patel (Ed.) The Cultural Politics of Europe. European Capitals of Culture and European Union since the 1980s, pp.19-38 (London: Routledge).

Zeitlin, J. (2005) Conclusion, in: J. Zeitlin \& P. Pochet with L. Magnusson (Eds) The Open Method of Co-ordination in Action: The European employment and social inclusion strategies, pp.447-503 (Brussels: PIE - Peter Lang S.A.).

Zeitlin, J. (2009) The Open Method of Coordination and reform of national social and employment policies: influences, mechanisms, effects, in: M. Heidenreich \& J. Zeitlin (Eds) Changing European Employment and Welfare Regimes: The Influence of the Open Method of Coordination on National Reforms, pp. 214-245 (London: Routledge).

Zeitlin, Jonathan (2011) Is the Open Method of Coordination an alternative to the Community Method? In: Dehousse, Renaud (ed). The 'Community Method': obstinate or obsolete? Basingstoke: Palgrave Macmillan. Pp. 135-147. 
Table 1. Priority A's Open Method of Coordination Working Groups

\begin{tabular}{|c|c|c|c|}
\hline & Group 1 & Group 2 & Group 3 \\
\hline Name & $\begin{array}{l}\text { The role of public arts and } \\
\text { cultural institutions in the } \\
\text { promotion of better access } \\
\text { to and wider participation } \\
\text { in culture }\end{array}$ & $\begin{array}{l}\text { The role of public arts and } \\
\text { cultural institutions in the } \\
\text { promotion of cultural } \\
\text { diversity and intercultural } \\
\text { dialogue }\end{array}$ & $\begin{array}{l}\text { Development of the key } \\
\text { competence 'Cultural } \\
\text { awareness and expression' }\end{array}$ \\
\hline Task & $\begin{array}{l}\text { Experts will identify } \\
\text { policies and good } \\
\text { practices of public arts } \\
\text { and cultural institutions to } \\
\text { promote better access to } \\
\text { and wider participation in } \\
\text { culture, including by } \\
\text { disadvantaged groups and } \\
\text { groups experiencing } \\
\text { poverty and social } \\
\text { exclusion }\end{array}$ & $\begin{array}{l}\text { Experts will identify } \\
\text { policies and good practices } \\
\text { in creating spaces in public } \\
\text { arts and cultural institutions } \\
\text { to facilitate exchanges } \\
\text { among cultures and } \\
\text { between social groups, in } \\
\text { particular by highlighting } \\
\text { the intercultural dimension } \\
\text { of the heritage and by } \\
\text { promoting artistic and } \\
\text { cultural education and } \\
\text { developing intercultural } \\
\text { competences. }\end{array}$ & $\begin{array}{l}\text { Experts will identify good } \\
\text { practices for the } \\
\text { development of this key } \\
\text { competence and its } \\
\text { integration into education } \\
\text { policies, on the basis of } \\
\text { knowledge and attitudes } \\
\text { identified in the } \\
\text { Recommendation of the } \\
\text { European Parliament and } \\
\text { of the Council of } 18 \\
\text { December } 2006 \text { on key } \\
\text { competences for lifelong } \\
\text { learning }\end{array}$ \\
\hline 8 & $\begin{array}{l}\text { Identification of policies } \\
\text { and good practice manual } \\
\text { for public arts and cultural } \\
\text { institutions. }\end{array}$ & $\begin{array}{l}\text { Identification of policies } \\
\text { and good practice manual } \\
\text { for public arts and cultural } \\
\text { institutions. }\end{array}$ & $\begin{array}{l}\text { Good practice manual for } \\
\text { culture and education } \\
\text { authorities at national and } \\
\text { European level. }\end{array}$ \\
\hline
\end{tabular}

Source: Council of the European Union (2010) 